\title{
Human Low-Density Lipoproteins: Oxidative Modification and Its Relation to Age, Gender, Menopausal Status and Cholesterol Concentrations ${ }^{1}$ )
}

\author{
Bedrich J. Mosinger
}

Institute for Clinical and Experimental Medicine, Prague, Czech Republic

Summary: Recently much evidence has accumulated indicating that oxidative modification of atherogenic lipoproteins plays an important role in atherogenesis. The goal of this study was to ascertain whether any association exists between this and the previously incriminated risk factors of atherosclerotic cardiovascular disease like age, gender and cholesterol concentration.

Serum lipid profile, low-density lipoprotein (LDL) composition and indicators of LDL oxidation were examined in a cohort of healthy, predominantly middle aged men and women. LDL oxidation was assessed using the copper catalysis method, and monitored routinely by the increase in conjugated dienes over 4 to 24 hours. A more objective computer-aided technique was used to estimate the oxidative indices based on the sigmoidal fit to data.

No marked differences between men and women were found with respect to mean age, total and LDL cholesterol, LDL protein and oxidation of LDL.

The post-menopausal as compared to pre-menopausal status was associated with a greater extent of LDL oxidation, as well as with higher total serum cholesterol and its fractions, LDL cholesterol and LDL protein. No such differences were found in the data for men appropriately separated according to age.

In a group with high risk LDL cholesterol, the total LDL oxidation was higher, as well as age and total cholesterol. Lag time and half-time of LDL oxidation were significantly shorter, while the oxidation rate of LDL was significantly faster when compared with data in the lower quartile.

About six percent of participants had a considerably prolonged initial oxidation phase. These persons also showed low total and LDL cholesterol. High oxidation resistance was reversible and most probably caused by very low pre-existent oxidation products.

Multiple regression analysis showed that the closest association among age, gender, lipid profiles and LDL oxidation indices existed between LDL cholesterol and conjugated diene production in both sexes (men: $r=0.93$; women: $\mathrm{r}=0.81$ ). This association remained high even if adjusted for age.

As in earlier epidemiological studies using logistic regression and showing age- and gender-related rising frequency of coronary heart disease, the present paper demonstrated age- and gender-related rising frequency of highly oxidized LDL. In both cases it was closely associated with an increasing LDL cholesterol concentration.

\section{Introduction}

There is strong experimental evidence that oxidized lowdensity lipoproteins (oxidized LDL) play an important role in atherogenesis. Above all, and in contrast to native LDL, they are recognizable by the non down-regulating macrophage scavenger receptor, resulting in the formation of foam cells characteristic of early-stage atherosclerosis $(1,2)$. The site and mode of endogenous oxidized LDL formation has not been identified as yet, little

\footnotetext{
1) The work was supported by a grant of the Ministry of Health, Prague, Czech Republic
}

is known about the oxidized LDL turnover rate, and many other questions remain unanswered $(3,52)$.

The incidence of coronary artery disease increases markedly with age in both men and women. Age, gender and menopausal status are major genetic risk factors for coronary artery disease, while the cholesterol concentration, diet and lifestyle are largely environmental risk factors in an otherwise healthy population (4-6).

In our previous study, we found a close association between cholesterol concentration and the extent of LDL oxidation, whereas the effects of age or gender were of marginal significance (7). 
This paper aims to evaluate data from a new cohort of the population with a broader age range. The effects of age, gender and menopausal status on the LDL oxidation indices became evident, and the development of high oxidized LDL formation was demonstrated using logistic regression.

\section{Materials and Methods}

Randomly sampled human sera from 104 healthy, predominantly blood donor volunteers ( 52 men and 52 women) were used fresh or stored at $+2{ }^{\circ} \mathrm{C}$ no longer than 3 days. Since the results obtained with fresh or stored sera did not differ appreciably, and serum is known to contain abundant endogenous antioxidants, these were not added in excess except after precipitation and redissolution of isolated LDL.

All the reagents, specific inhibitors and lipid substrates used were of reagent grade and were purchased from Sigma Chemical Company (St. Louis, Mo, USA), Merck (Darmstadt, Germany) and Lachema (Brno, Czech Republic).

Commercial kits for the enzymatic determination of cholesterol in serum were from Lachema-Diagnostica (Brno, CR). Cholesterol in isolated LDL was determined by the same method, but using a proportionately greater volume than that for the measurement of serum cholesterol and treating the standard cholesterol solution in the same way.

Precipitation reagent for LDL isolation (cat. No. 14992) was from Merck (Darmstadt, Germany).

Physiological salt solution was Krebs-Henseleit buffer containing (in mmol/l): $118 \mathrm{NaCl}, 4.7 \mathrm{KCl}, 1.2 \mathrm{KH}_{2} \mathrm{PO}_{4}, 2.5 \mathrm{MgSO}_{4}, 25$ $\mathrm{NaHCO}_{3}, 11$ glucose, and $1 \mathrm{CaEDTA}$ and saturated with $95 \% \mathrm{O}_{2}$ plus $5 \% \mathrm{CO}_{2}$.

Protein content was measured as described by Bradford (8) and verified by the Lowry method (9) and optical absorbance at 210 and/or $280 \mathrm{~nm}$. No interference with any component of Merck's precipitation reagent in the expected concentration range was found.

\section{Preparation of low-density lipoprotein}

A rapid precipitation technique convenient for serial assays was preferred. It was based on the formation of a complex of heparin with LDL at an isoelectric point. An almost perfect correlation with ultracentrifugation or quantitative electrophoresis was found (10). The precipitation technique considerably shortens the pre-oxidative preparation of LDL. Moreover, it is believed that the complexed LDL is structurally similar to the LDL that exists in vivo after entering the arterial wall and binding to the arterial glucosaminoglycans $(11-14)$.

Briefly, LDL isolation was carried out according to the manufacturer's instructions (Merck) by mixing in a centrifugation tube with a conical bottom, $0.5 \mathrm{ml}$ of serum with $5 \mathrm{ml}$ of precipitation solution at laboratory temperature, followed by $10 \mathrm{~min}$ standing, then centrifugation at $2000 \mathrm{~g}$ for $10 \mathrm{~min}$. The supernatant was discarded. The inner wall of the tube with the open end turned down was thoroughly washed just above the precipitate to completely remove the residues of serum and precipitation solution, using a micropipette connected to a redistilled water reservoir.

The precipitate of LDL was dissolved in $10 \mathrm{ml}$ of warm KrebsHenseleit solution $\left(37^{\circ} \mathrm{C}\right)$ with slow and gentle stirring of the precipitate with a tiny glass rod. Thus, the final concentration of a clear solution of LDL was 20 times lower than its original serum concentration. Reproducibility of the method was found to be satisfactory with a variation coefficient of about $7 \%$.

The analysis (protein, cholesterol) and subsequent experiments with isolated LDL were started immediately.

\section{Oxidative modification of low-density lipoproteins}

From several available methods, the most frequently used copperinduced oxidation method was chosen (1). Briefly, $2.5 \mathrm{ml}$ of LDL samples and copper sulphate at a final concentration of $10 \mu \mathrm{mol} / \mathrm{l}$ (routine assay) were mixed directly in photometry quartz cuvettes $(1 \times 1 \mathrm{~cm})$, closed and incubated for $4-24 \mathrm{~h}$ at $37^{\circ} \mathrm{C}$ in a water bath. The formation of conjugated dienes was monitored every 15-30 minutes according to Esterbauer (15). Both wavelength scanning between 220 and $300 \mathrm{~nm}$ and multiwavelength photometry close to the absorbance peak were used. Peak differential absorbance was close to $234 \mathrm{~nm}$.

The absorbance units were recalculated to conjugated dienes using a molar absorbance coefficient $\varepsilon$ of $2950 \mathrm{~m}^{2} / \mathrm{mol}$ (16).

The kinetics of $\mathrm{Cu}^{2+}$-catalysed oxidation of LDL were similar to those of LDL isolated by ultracentrifugation $(7,16)$. On the other hand the correct quantitative comparison of oxidative indices in both methods was very difficult in the absence of any standardized method. For instance the oxidation lag time of LDL isolated ultracentrifugally could vary from $15 \mathrm{~min}$ (17) to $242 \mathrm{~min}(18)$ and reported times also vary in the same publication, using the same isolation technique. The reason is the notorious instability of isolated LDL and its unexpected sensitivity to various manipulations.

\section{Statistical analysis}

Data are expressed as means $\pm \mathrm{SD}$, and $\mathrm{N}$ refers to the number of analysed individual serum samples. ANOVA and t-tests were used to evaluate the statistical significance of differences. A two-tailed probability value $P<0.05$ was considered to be statistically significant. Quantities of LDL oxidation kinetics were calculated from the sigmoidal fit (Borland) to experimental data. The obtained primitive regression functions permit the easy calculation of their first or higher order derivatives, which enable a more objective demonstration of some analytical results. These and other statistical tests, correlation coefficients and regression parameters were calculated using computer-aided programs (ORIGIN, MicroCal Software Inc., STATISTICA, Statsoft and EXCEL, Microsoft).

\section{Results}

\section{Basic characteristics and stratification analysis of examined group}

a) Most participants in the study were voluntary blood donors without any manifest disease or abnormal lifestyle. Average data for age, serum and LDL cholesterol, LDL protein and the indices of LDL oxidation are summarized in table 1. LDL oxidation indices calculated from sigmoidal fit to the LDL oxidation time course are explained in figure 1 . There were no marked differences between men and women: slightly higher total serum cholesterol, a shorter lag time and higher rate of LDL oxidation were found in women than in men.

b) In our group we found about 6 percent of persons with a very prolonged initial oxidation phase, mostly longer than $240 \mathrm{~min}$. No obvious association was found with this phenomenon, except the fact that these individuals exhibited very low total (mean 3.3, range 2.8-4.7 $\mathrm{mmol} / \mathrm{l}$ ) and LDL cholesterol concentration (mean 1.28, range $0.8-2.0 \mathrm{mmol} / 1$ ).

c) In contrast to average data of all men and women as shown in table 1, the data of women over 50 years - the menopausal age generally recognized as a risk factor of 
Tab. 1 Characteristics of examined group of men and women.

\begin{tabular}{|c|c|c|c|c|}
\hline Variable & $\begin{array}{l}\text { All subjects } \\
\mathrm{N}=104\end{array}$ & $\begin{array}{l}\text { Men } \\
N=52\end{array}$ & $\begin{array}{l}\text { Women } \\
\mathrm{N}=52\end{array}$ & $\mathbf{P}$ \\
\hline Age (years) & $38.7 \pm 11.9$ & $37.0 \pm 11.8$ & $40.2 \pm 11.9$ & ns \\
\hline Total serum cholesterol $(\mathrm{mmol} / \mathrm{l})$ & $4.7 \pm 0.9$ & $4.5 \pm 1.0$ & $5.0 \pm 0.9$ & 0.03 \\
\hline LDL cholesterol $(\mathrm{mmol} / \mathrm{l})$ & $2.9 \pm 0.8$ & $2.8 \pm 0.98$ & $3.0 \pm 0.87$ & ns \\
\hline Lag time $(\min )^{\mathrm{a}}$ & $90.7 \pm 58.4$ & $103.2 \pm 71.7$ & $78.1 \pm 37.7$ & 0.03 \\
\hline Half-time $(\min )^{b}$ & $143.6 \pm 197.5$ & $179.2 \pm 241.1$ & $107.9 \pm 129.0$ & ns \\
\hline Rate $(\mu \mathrm{mol} / 1 \cdot \min )^{\mathrm{c}}$ & $0.48 \pm 0.1$ & $0.43 \pm 0.1$ & $0.52 \pm 0.2$ & 0.02 \\
\hline Oxidized LDL (Diene) $(\mu \mathrm{mol} / 1)^{d}$ & $22.8 \pm 8.2$ & $21.8 \pm 9.4$ & $23.7 \pm 6.7$ & ns \\
\hline
\end{tabular}

Data expressed as means $\pm \mathrm{SD}$.

Data of oxidized $L D L$ samples:

Mean protein concentration: $0.1 \pm 0.07 \mathrm{~g}$ per litre of isolated LDL.

a Induction phase of LDL oxidation corresponding to 20 percent of total net increase of absorbance (see "lag time" in fig. 1).

b Half-time (see fig. 1) of LDL oxidation.

c Maximum rate of absorbance change (see fig. 1) expressed in the

cardiovascular diseases - were higher in many variables than those of younger women. This was not the case for men. Among the LDL oxidation indices, total oxidation was significantly higher in elderly women (tab. 2).

d) To investigate the association of another established risk factor of atherosclerosis with the indices of LDL oxidation in the same individual, the whole cohort was stratified into lower and higher LDL cholesterol (i.e. $<3.6 \mathrm{mmol} / 1$ and $>3.6 \mathrm{mmol} / \mathrm{l}$ ), corresponding to lower or higher risk of atherosclerosis and comprising

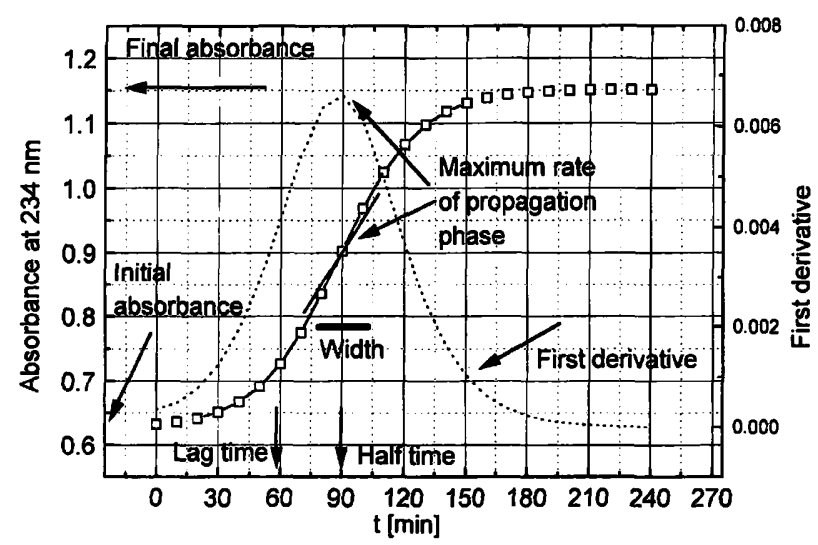

Fig. 1 LDL oxidation, showing fit to sigmoidal regression function and its first derivative.

The coefficients of the equation

$$
y=(I A-F A) /(1+\exp (x-H T) / W)+F A
$$

calculated by the least squares method (quasi-Newton) were: absorbance before (IA) and at the end (FA) of LDL oxidation; $(\mathrm{FA}-\mathrm{IA})=$ total LDL oxidation; lag time $=$ induction phase of LDL oxidation; half-time = time when half of the difference between initial and final absorbance has been reached; width $=$ time interval of fastest propagation phase. The symbols $y$ and $x$ in the equation stand for the data on the vertical and/or horizontal axis.

Maximum rate of propagation phase (MR) can be calculated according to the formula: $\left(\mathrm{y}_{2}-\mathrm{y}_{1}\right) / \mathrm{W}$, where $\mathrm{y}_{1}=(\mathrm{IA}-\mathrm{FA}) /$ $(1+\exp (-0.5))+\mathrm{FA}$, and $\mathrm{y}_{2}=(\mathrm{IA}-\mathrm{FA}) /(1+\exp (0.5))+\mathrm{FA}$. In a simplified formula, maximum rate $=[(\mathrm{IA}-\mathrm{FA}) \mathrm{x}-0.245] / \mathrm{W}$. (MR can also be assessed according to the peak of the first derivative of primitive function).
$\mathrm{P}=$ Significance between men and women (2-tailed t-test): ns $=$ not significant.

oxidized LDL (diene) production per litre of isolated LDL (corresponding to $50 \mathrm{ml}$ of serum) per min.

d Maximal increase of absorbance (see Final absorbance (FA)Initial absorbance (IA) in fig. 1) expressed as the conjugated diene concentration per litre of isolated LDL (corresponding to $50 \mathrm{ml}$ of serum).

about $75 \%$ and $25 \%$ of all participants, respectively. The average value of LDL cholesterol was $2.5 \pm 0.6$ and 4.2 $\pm 0.42 \mathrm{mmol} / 1$ in the lower risk and higher risk group, respectively. As can be seen in table 3, these two groups differed in age, serum total cholesterol and the extent of LDL oxidation. They did not differ in half-time, lag time or the oxidation rate. The tendency of half-time or lag time to be shorter and the rate of oxidation to be higher in the higher risk group was nevertheless evident and these quantities were significantly different from those in the bottom quartile (tab. 3).

Virtually the same results were obtained if stratification was made according to lower and higher total serum cholesterol (i. e. $<5.2$ and $>5.2 \mathrm{mmol} / \mathrm{l}$ ).

\section{Correlation coefficients of LDL oxidation indices versus age, LDL cholesterol and LDL protein}

The matrix of selected correlation coefficients between LDL oxidation indices on the one hand, and age, total

Tab. 2 Cholesterol and indices of LDL oxidation. Effect of menopausal state.

\begin{tabular}{lll}
\hline Variables & \multicolumn{2}{l}{ Menopausal state } \\
\cline { 2 - 3 } & no & yes \\
& $\mathrm{N}=36$ & $\mathrm{~N}=12$ \\
\hline Age (years) & $35.8 \pm 10.3$ & $53.6 \pm 3.4^{* * *}$ \\
$\begin{array}{l}\text { Total serum cholesterol } \\
\text { (mmol/l) }\end{array}$ & $4.6 \pm 0.74$ & $5.9 \pm 0.82^{* * *}$ \\
LDL cholesterol (mmol/l) & $2.7 \pm 0.76$ & $3.6 \pm 0.98^{* *}$ \\
Lag time (min) & $78.9 \pm 41.8$ & $76.8 \pm 27.3$ \\
Half-time (min) & $113.5 \pm 151.2$ & $95.2 \pm 31.9^{*}$ \\
Rate ( $\mu \mathrm{mol} / \mathrm{l} \cdot \min )$ & $0.51 \pm 0.20$ & $0.53 \pm 0.2$ \\
Oxidized LDL (Diene) & $22.3 \pm 5.9$ & $28.1 \pm 7.8^{* * *}$ \\
$\quad(\mu \mathrm{mol} / \mathrm{l})$ & & \\
\hline
\end{tabular}

Data expressed as means \pm SD.

Statistical significance:

$* * * \mathrm{P}<0.0001 ; * * \mathrm{P}<0.01$ (2-tailed t-test);

$* \mathrm{P}<0.0001$ (F-test). Otherwise see table 1 . 
Tab. 3 Age, cholesterol and LDL oxidation indices in lower and higher risk LDL cholesterol group.

\begin{tabular}{lll}
\hline & $\begin{array}{l}\text { Lower risk } \\
\text { group }\end{array}$ & $\begin{array}{l}\text { Higher risk } \\
\text { group }\end{array}$ \\
\hline Age (years) & $36.4 \pm 11.8$ & $\begin{array}{l}46.6 \pm 8.6^{\mathrm{a}} \\
(\mathrm{N}=21)\end{array}$ \\
$\begin{array}{l}\text { Total serum cholesterol } \\
\text { (mmol/l) }\end{array}$ & $\begin{array}{l}\mathrm{N}=74) \\
(\mathrm{N}=77)\end{array}$ & $\begin{array}{l}5.9 \pm 0.77^{\mathrm{a}} \\
(\mathrm{N}=23)\end{array}$ \\
$\begin{array}{l}\text { LDL cholesterol } \\
\text { (mmol/l) }\end{array}$ & $2.5 \pm 0.6$ & $4.2 \pm 0.42^{\mathrm{a}}$ \\
$\begin{array}{l}\text { Oxidized LDL } \\
\text { (Diene) }(\mu \mathrm{mol} / \mathrm{l})\end{array}$ & $(\mathrm{N}=77)$ & $(\mathrm{N}=23)$ \\
$\begin{array}{l}\text { Lag time } \\
\text { (min) }\end{array}$ & $20.1 \pm 7.0$ & $31.8 \pm 5.0^{\mathrm{a}}$ \\
Half-time & $(\mathrm{N}=77)$ & $(\mathrm{N}=23)$ \\
$(\mathrm{min})$ & $94.1 \pm 65.4$ & $78.9 \pm 18.3^{\mathrm{b}}$ \\
Rate & $(\mathrm{N}=77)$ & $(\mathrm{N}=23)$ \\
$(\mu \mathrm{mol} / \mathrm{l} \cdot \mathrm{min})$ & $156.9 \pm 223.4$ & $98.8 \pm 20.8^{\mathrm{b}}$ \\
\hline
\end{tabular}

Data expressed as means \pm SD.

Lower or higher risk group: LDL cholesterol $<3.6 \mathrm{mmol} / 1$ or $>3.6 \mathrm{mmol} / \mathrm{l}$.

Lower quartile data: Lag time $118.8 \pm 90.1$; Half time 243.6 \pm 319.4 ; Rate $0.42 \pm 0.21$.

a Significant difference between lower and higher risk group.

b Significant difference between lower quartile data and higher risk group.

Otherwise see table 1.

cholesterol, LDL cholesterol and LDL protein on the other hand is demonstrated in table 4 . The closed positive association was demonstrated between the extent of LDL total oxidation and LDL cholesterol, as well as between starting LDL absorbance and LDL protein. This was true in both men and women. A negative association of LDL cholesterol with LDL oxidative resistance (half-time or lag time) was significant only in men. Whereas LDL cholesterol (LDLc) was related linearly to the extent of oxidation, it was related non-linearly to the lag time (U-shaped curve) with the quadratic regression function: Lag time $=353.7-167.1 \times$ LDL-c $+23.9 \times(\text { LDL-c })^{2}$. Minimum lag time (calculated under the condition that the first derivative equalled zero) corresponded to $3.5 \mathrm{mmol} / \mathrm{l}$ of LDL cholesterol (LDLc). The rate of LDL oxidation was significantly and positively associated with LDL cholesterol in both men and women.

\section{Multiple linear regression analysis of LDL oxidation}

Because the interrelation between the variables, as demonstrated in table 4, was not necessarily independent, multivariate regression analysis was carried out. The results given in table 5 show that the extent of LDL total oxidation was positively and most closely associated with LDL cholesterol, less so with the rate of oxidation and negatively associated with the lag time in both sexes.

\section{Logistic regression of age, gender and high oxidized LDL}

The abnormally high values of LDL oxidation were defined by the data in the range of the upper quintile. The relation between the incidence of high LDL oxidation and age in men and women is depicted in figure 2. Whereas the frequency of high oxidation increased monotonously with age in men, this relation was complex in women. In premenopausal age the frequency was smaller than in men, but around menopausal age it started to increase markedly and reached and/or exceeded the values of men. Using bivariate analysis, the age-controlled frequency was higher in men than in women within a younger age range (odds ratio 3.56 , 95\% confidence interval: $1.5-5.56$ ) whereas after 50 years the frequency was virtually gender-independent

Tab. 4 Correlation coefficient matrix of age, total cholesterol, LDL cholesterol and LDL protein with low-density lipoprotein oxidation indices in men and women.

\begin{tabular}{|c|c|c|c|c|c|c|c|c|c|c|}
\hline \multirow[t]{2}{*}{ Variable } & \multicolumn{2}{|c|}{$\begin{array}{l}\text { Initial LDL } \\
\text { absorbance } \\
\mathrm{A}_{234 \mathrm{~nm}}^{1 \mathrm{~cm}}\end{array}$} & \multicolumn{2}{|c|}{$\begin{array}{l}\text { Oxidized LDL } \\
\text { (Diene) } \\
(\mu \mathrm{mol} / \mathrm{l})\end{array}$} & \multicolumn{2}{|c|}{$\begin{array}{l}\text { Half-Time } \\
\text { (min) }\end{array}$} & \multicolumn{2}{|c|}{$\begin{array}{l}\text { Lag Time } \\
(\min )\end{array}$} & \multicolumn{2}{|c|}{$\begin{array}{l}\text { Rate } \\
(\mu \mathrm{mol} / 1 \cdot \min )\end{array}$} \\
\hline & $\delta$ & q & $\hat{\sigma}$ & q & $\delta$ & q & $\delta$ & 우 & $\delta$ & $q$ \\
\hline Age (years) & $0.45^{\mathrm{a}}$ & ns & $0.54^{\mathrm{a}}$ & $0.42^{b}$ & ns & ns & ns & ns & $0.32^{\mathrm{c}}$ & ns \\
\hline $\begin{array}{l}\text { Total serum cholesterol } \\
(\mathrm{mmol} / \mathrm{l})\end{array}$ & $0.60^{\mathrm{a}}$ & $0.42^{\mathrm{b}}$ & $0.75^{\mathrm{a}}$ & $0.67^{\mathrm{a}}$ & $-0.42^{b}$ & ns & $-0.37^{b}$ & $\mathrm{~ns}$ & $0.34^{\mathrm{c}}$ & ns \\
\hline $\begin{array}{l}\text { LDL cholesterol } \\
(\mathrm{mmol} / \mathrm{l})\end{array}$ & $0.68^{\mathrm{a}}$ & $0.43^{\mathrm{b}}$ & $0.89^{\mathrm{a}}$ & $0.69^{\mathrm{a}}$ & $-0.48^{\mathrm{a}}$ & ns & $-0.47^{a}$ & ns & $0.45^{\mathrm{b}}$ & $0.27^{\mathrm{c}}$ \\
\hline LDL cholesterol/protein & ns & ns & $0.93^{\mathrm{a} *}$ & $0.81^{\mathrm{a*}}$ & $-0.40^{b}$ & ns & $-0.43^{b}$ & ns & $0.72^{\mathrm{a} * *}$ & $0.60^{\mathrm{a} * *}$ \\
\hline $\begin{array}{l}\text { LDL protein } \\
(\mathrm{g} / \mathrm{l})\end{array}$ & $0.83^{\mathrm{a}}$ & $0.66^{\mathrm{a}}$ & ns & ns & ns & ns & ns & ns & ns & ns \\
\hline
\end{tabular}

Data expressed as means $\pm \mathrm{SD}$.

$\mathrm{ns}=\mathrm{P}$ not significant.

${ }^{\mathrm{a}} \mathrm{P}<0.001 ;^{\mathrm{b}} \mathrm{P}<0.01 ;^{\mathrm{c}} \mathrm{P}<0.05$.
* oxidized LDL (Diene) (nmol/mg protein).

** Rate (nmol/mg protein).

Otherwise see table 1 . 
Tab. 5 Multiple regression analysis of LDL oxidation where oxidized LDL (Diene) is the dependent variable.

\begin{tabular}{|c|c|c|c|c|c|}
\hline & \multicolumn{2}{|l|}{ Raw data } & & \multicolumn{2}{|l|}{ Raw data } \\
\hline & $\begin{array}{l}\text { Partial } \\
\text { correlation } \\
\text { coefficient }\end{array}$ & $\mathbf{P}$ & & $\begin{array}{l}\text { Partial } \\
\text { correlation } \\
\text { coefficient }\end{array}$ & $\mathbf{P}$ \\
\hline \multicolumn{6}{|l|}{ All subjects: } \\
\hline Diene $(\mu \mathrm{mol} / \mathrm{l})$ & & & Diene* & & \\
\hline Age (years) & 0.22 & 0.04 & Age (years) & 0.03 & ns \\
\hline LDL cholesterol $(\mathrm{mmol} / \mathrm{l})$ & 0.69 & $<0.00001$ & LDL cholesterol* & 0.85 & $<0.0001$ \\
\hline LDL protein $(\mathrm{g} / \mathrm{l})$ & 0.18 & ns & LDL protein $(\mathrm{g} / \mathrm{l})$ & 0.32 & $<0.01$ \\
\hline Lag time (min) & -0.61 & $<0.00001$ & Lag time (min) & -0.75 & $<0.0001$ \\
\hline Rate $(\mu \mathrm{mol} / 1 \cdot \min )$ & 0.45 & $<0.00001$ & Rate* & 0.62 & $<0.0001$ \\
\hline \multicolumn{6}{|l|}{ Men: } \\
\hline Diene $(\mu \mathrm{mol} / \mathrm{l})$ & & & Diene* & & \\
\hline Age (years) & 0.16 & ns & Age (years) & 0.11 & ns \\
\hline LDL cholesterol $(\mathrm{mmol} / \mathrm{l})$ & 0.83 & $<0.00001$ & LDL cholesterol* & 0.86 & $<0.0001$ \\
\hline LDL protein $(\mathrm{g} / \mathrm{l})$ & -0.03 & ns & LDL protein $(\mathrm{g} / \mathrm{l})$ & 0.43 & $<0.001$ \\
\hline lag time (min) & -0.76 & $<0.00001$ & Lag time (min) & -0.87 & $<0.0001$ \\
\hline Rate $(\mu \mathrm{mol} / 1 \cdot \min )$ & 0.55 & $<0.0001$ & Rate* & 0.71 & $<0.0001$ \\
\hline \multicolumn{6}{|l|}{ Women: } \\
\hline Diene $(\mu \mathrm{mol} / \mathrm{l})$ & & & Diene* & & \\
\hline Age (years) & 0.24 & ns & Age (years) & 0.13 & ns \\
\hline LDL cholesterol $(\mathrm{mmol} / \mathrm{l})$ & 0.56 & $<0.00001$ & LDL cholesterol* & 0.85 & $<0.0001$ \\
\hline LDL protein $(\mathrm{g} / \mathrm{l})$ & 0.34 & 0.02 & LDL protein $(\mathrm{g} / \mathrm{l})$ & 0.38 & $<0.05$ \\
\hline Lag time (min) & -0.47 & $<0.001$ & Lag time (min) & -0.66 & $<0.0001$ \\
\hline Rate $(\mu \mathrm{mol} / 1 \cdot \min )$ & 0.43 & 0.003 & Rate* & 0.67 & $<0.0001$ \\
\hline
\end{tabular}

* Data normalized per protein unit.

$\mathbf{P}=$ statistical significance.

ns $=$ not significant.

Otherwise see table 1 .

in men and 47.5 years in women. The time to reach a $50 \%$ frequency was 55.5 years in men and 54.1 years in women and maximum increase of frequency was $1.3 \%$ per year in men and $5 \%$ per year in women.

The curves of instantaneous change of frequency (first derivative) as demonstrated in the insert of figure 2 underline marked gender differences as affected by age.

The incidence of high LDL oxidation as related to the LDL cholesterol (in comparison with age) is included in the same picture. There is small gender difference. However, in the range of 3-4 $\mathrm{mmol} / \mathrm{l}$ of LDL cholesterol there was a trend to a lower incidence of oxidation in women than in men.

A similar processing of data for lag time and/or the rate of LDL oxidation did not indicate that they are dependent on age.

\section{Discussion}

Fig. 2 Logistic function of the frequency of high concentrations of oxidized LDL as related to age and/or the LDL cholesterol concentration.

Note that the difference between men and women is more marked if the frequency is related to age rather than to LDL cholesterol.

The inserted picture demonstrates the changes of frequency with age (first derivative of main picture curves). The different types of changes between men and women, but exhibiting the peak at similar age, are apparent.
The extent of LDL oxidation is thought to be largely indicated by the amount of polyunsaturated fatty acids in cholesterol esters, which serve as the oxidizable substrate in the formation of conjugated diene. On the other hand, the mechanism and/or the determinants of lag time, half-time or oxidation rate are less clear (18-23). 
From table 1, an influence of gender either on the average LDL composition or LDL oxidation indices is hardly apparent.

However, after dividing the population sample into younger and older men or women (i. e. pre- and menopausal status), the effect of age was clearly genderdependent (tab. 2). LDL oxidation, together with total or serum cholesterol fractions, was significantly higher in older than in younger women. No significant differences were found in men, however. As also indicated by the next analysis, related increments of dependent variables approach their maximum asymptotically in men around the age of 50 years, but not in women.

The finding that the premenopausal state had a beneficial effect on total oxidation but not on the resistance of LDL oxidation (i. e. lag time or half-time) was unexpected. In several papers it has been shown that the administration of a small amount of oestrogen increased LDL oxidation resistance in in vitro as well as in ex vivo experiments $(24-26)$. The reason for our failure to find this effect in our LDL samples of young women could be accounted for by the fact that a supraphysiological concentration of oestrogen was used in some of the mentioned experimental work. In Sack's clinical study (26) two groups of post-menopausal women, with and without oestrogen administration, were compared; but in contrast to the present work, Sack's study did not include a comparison of untreated pre- and post-menopausal women.

The other explanation, i. e. that we included in our group some elderly menopausal women with normal oestrogen levels seems to be very unlikely. Major changes in oestrogen occur in the immediate post-menopausal period, with little subsequent change with age. In addition some recent papers seriously question any role of endogenous oestrogen (in contrast to exogenous oestrogen) in coronary heart disease. Accordingly, this role is more significantly associated with the age of women $(27,28)$.

Nonetheless the possibility cannot be entirely excluded that we removed part of the endogenous oestrogen during isolation or by dilution of LDL. It is conceivable that special precautions are needed during the isolation and purification of LDL in order to see the effect of endogenous oestrogens.

The stratification of all participants according to lower and higher risk LDL cholesterol revealed that the extent of LDL oxidation was greater in the latter group, but there was no significant change in the half-time, lag time and the rate of oxidation (tab. 3). The lack of significance was probably due to the high standard deviation of means resulting from the occurrence of several very low susceptibility data associated with the low total and
LDL cholesterol. The initial oxidation phase of these samples was much longer than expected from linear extrapolation.

We observed a similar disproportionate prolongation of lag time related to low LDL cholesterol levels in earlier work on the oxidation of animal LDL (7), suggesting that these two variables in general are related in a nonlinear fashion. Absence of preformed lipid hydroperoxides - an important determinant of the LDL oxidative susceptibility - could be a likely explanation $(21,22)$. Support for such a hypothesis was provided by the fact that a trace amount of oxysterol added to the LDL preparations was sufficient not only to restore normal oxidation kinetics but in fact to eliminate completely the initial phase (not shown). Thus the possibility was excluded that these particular LDL samples were damaged irreversibly.

The abnormally low level of cholesterol has been found in other studies in about $3-6 \%$ of the Western population, which is similar to the frequency found in the present paper. The expression of recently identified apolipoprotein B mutations might be involved (29). The problem of low cholesterolaemia is currently under considerable debate because of its assumed association with mental disorders (depression, suicides etc.) or cancer $(30-42)$. The association could not be confirmed or ruled out in the present study because the relevant participants were predominantly younger people (mean 30.8 years, range $21-45$ years) and serious clinical manifestation could appear a decade later (33). If the mentioned non-cardiovascular diseases are causally linked to the low cholesterolaemia, then the associated unusually high resistance to oxidation of appropriate LDL as found in this paper could partly contribute to the underlying mechanism.

The correlation matrix (tab. 4) and multivariate regression analysis (tab. 5) showed that the maximum of LDL oxidation was primarily related to the cholesterol content in LDL and associated with the shortening of lag time and the increase of oxidation rate. Bivariate analysis showed that the greater the extent of total oxidation, the shorter the initial phase and the greater the oxidation rate.

Earlier epidemiological studies have shown repeatedly (4-6) that the incidence of cardiovascular complications of atherosclerosis increase with the age of participants of both sexes. Because of the proposed involvement of LDL oxidation in atherogenesis, the question arose as to whether an analogous relation exists between this variable and age. Logistic analysis showed that such a correlation exists, and that the development of high LDL oxidation occurs differently in men and women. Whereas the frequency of high LDL oxidation increased monotonously and steadily in men between the ages of 
20 and 70 years, younger women showed a very low frequency, which then increased rapidly during the menopause. The significance of the age factor decreased dramatically if adjusted for LDL cholesterol.

The occurrence of abnormal susceptibility of LDL to oxidation (abnormal lag time or oxidation rate) did not increase with age.

All the mentioned facts strongly suggest that the role of the age factor is largely related to LDL cholesterol development. We recalculated other recently published data (5) on age - related risk LDL cholesterol, and found a very similar time course, as shown in figure 2 .

At the present time, there are increasing numbers of reports indicating that resistance of LDL to oxidation (e. g. following antioxidant administration) does not always correlate satisfactorily to the development of atherosclerosis, especially in cases of elevated cholesterol in serum $(43-50)$. It was also found that LDL of patients treated

\section{References}

1. Steinberg D, Parthasarathy S, Carew TE, Khoo JC, Witztum JL. Beyond cholesterol. Modifications of low-density lipoprotein that increase its atherogenicity. N Engl J Med 1989; 320:915-24.

2. Steinberg D. Modified forms of low-density lipoprotein and atherosclerosis [minireview]. J Inter Med 1993; 233:227-32.

3. Steinberg D. Clinical trials of antioxidants in atherosclerosis: are we doing the right thing? Lancet $1995 ; 346: 36-8$.

4. Grundy SM (head of panel). Summary of the Second Report of the National Cholesterol Education Program (NCEP). Expert Panel on Detection, Evaluation, and Treatment of High Blood Cholesterol in Adults (Adult Treatment Panel II). J Am Med Assoc 1993; 269:3015-23.

5. Schaefer EJ, Lamon-Fava S, Cohn SD, Schaefer MM, Ordova JM, Castelli WP, et al. Effects of age, gender, and menopausal status on plasma low density lipoprotein cholesterol and apolipoprotein B levels in the Framingham Offspring Study. J Lipid Res 1994; 35:779-92.

6. Schaefer EJ, Lichtenstein AH, Lamonfava S, McNamara JR, Ordovas JM. Lipoproteins, nutrition, aging, and atherosclerosis. Am J Clin Nutr 1995; 61 Suppl:S726-40.

7. Mosinger BJ. Copper-induced and photosensitive oxidation of serum low-density lipoprotein. The relation to cholesterol level and inter-species differences. Biochim Biophys Acta 1995; $1270: 73-80$

8. Bradford M. A rapid and sensitive method for the quantitation of microgram quantities of protein utilizing the principle of protein-dye binding. Anal Biochem 1976; 72:248-54.

9. Lowry OH, Rosebrough NJ, Farr AL, Randall RJ. Protein measurement with the folin phenol reagent. J Biol Chem 1951; 193:265-75

10. Wieland H, Seidel D. A simple specific method for precipitation of low density lipoprotein. J Lipid Res 1983; 24:904-9.

11. Zhang A, Vertommen J, Van Gaal L, De Leeuw I. A rapid and simple method for measuring the susceptibility of low-densitylipoprotein and very low-density-lipoprotein to copper-catalyzed oxidation. Clin Chim Acta 1994; 227:159-73.

12. Sutherland WHF. Oxidation of heparin-isolated LDL by hemin. The effect of serum components. Arterioscler Thromb 1994; 14:1966-75.

13. McDowell IFW, McEneny J, Trimble ER. A rapid method for measurement of the susceptibility to oxidation of low-density lipoprotein. Ann Clin Biochem 1995; 32:167-74. with hypocholesterolaemic drugs contained lower LDL cholesterol, accompanied by a decreased extent of oxidation and no change in the oxidation lag phase (51). These papers are in keeping with our results, suggesting that the extent of LDL oxidation, related closely to cholesterol content, and associated with oxidative kinetics, represents an important risk factor for atherosclerosis development.

In conclusion it should be noted, however, that in vivo the quantity of oxidized LDL, as the ultimate and decisive atherogenic determinant, results from a multifactorial process. It is given not only by a complex time function of LDL concentration and size, lag time and the rate of oxidation, but also by the net uptake of LDL and decomposition rate of oxidized LDL.

\section{Acknowledgements}

The author wishes to thank Mrs. M. Pilatova for her expert technical assistance.

14. Ahotupa M, Ruutu M, Mantyla E. Simple methods of quantifying oxidation products and antioxidant potential of low density lipoproteins. Clin Biochem 1996; 29:139-44.

15. Esterbauer H, Striegel G, Puhl H, Rothneder M. Continuous monitoring of in vitro oxidation of human low density lipoprotein. Free Radical Res Commun 1989; 6:67-75.

16. Kleinveld HA, Hak-Lemmers HLM, Stalenhoef AFH, Demacker PNM. Improved measurement of low-density-lipoprotein susceptibility to copper-induced oxidation - application of a short procedure for isolating low-density lipoprotein. Clin Chem 1992; 38:2066-72.

17. Hallenberg C, Haden M, Bergstrom M, Hanson G, Petterson $\mathrm{K}$, Westerlund $\mathrm{Ch}$, et al. Lipoprotein fraction in deuterium oxide gradients: a procedure for evaluation of antioxidant binding and susceptibility to oxidation. J Lipid Res 1994; 35:1-9.

18. Frei B, Gaziano JM. Content of antioxidants, preformed lipid hydroperoxides and cholesterol as predictors of the susceptibility of human LDL to metal ion-dependent and ion-independent oxidation. J Lipid Res 1993; 34:2135-45.

19. Kleinveld HA, Naber AHJ, Stalenhoef AFH, Demacker PNM. Oxidation resistance, oxidation rate and extent of oxidation of human low-density lipoprotein depend on the ratio of oleic acid content to linoleic acid content - studies in vitamin-E deficient subjects. Free Radical Biol Med 1993; 15:273-80.

20. Lynch SM, Frei B. Mechanisms of copper-dependent and irondependent oxidative modification of human low density lipoprotein. J Lipid Res 1993; 34:1745-53.

21. Thomas JP, Kalyanaraman B, Girotti AW. Involvement of preexisting lipid hydroperoxides in $\mathrm{Cu}^{2+}$-stimulated oxidation of low-density lipoprotein. Arch Biochem Biophys 1994; 315:244-54.

22. Schnitzer E, Fainaru M, Lichtenberg D. Oxidation of low density lipoprotein upon sequential exposure to copper ions. Free Radical Res 1995; 23:137-49.

23. Lynch SM, Frei B. Reduction of copper but not iron by human low density lipoprotein LDL. - Implications for metal iondependent oxidative modification of LDL. J Biol Chem 1995; 270:5158-63.

24. Maziere C, Auclair M, Ronveaux M, Salmon S, Santus R, Maziere J. Estrogens inhibit copper and cell-mediated modification of low density lipoprotein. Atherosclerosis 1991; $89: 175-82$. 
25. Riffici VA, Khachadurian AK. The inhibition of low-density lipoprotein oxidation by 17-beta-estradiol. Metabolism 1992; 41:1110-4.

26. Sack MN, Rader DJ, Cannon III RO. Oestrogen and inhibition of oxidation of low-density lipoproteins in postmenopausal women. Lancet 1994; 343:269-70.

27. Cauley JA, Gutai JP, Glynn NW, Paternostrobayles M, Cottington E, Kuller LH. Serum estrone concentrations and coronary artery disease in postmenopausal women. Arterioscler Thromb 1994; 14:14-8.

28. Casiglia E, Deste D, Ginocchio G, Colangeli G, Onesto C, Tramontin P, et al. Lack of influence of menopause on blood pressure and cardiovascular risk profile: a 16-year longitudinal study concerning a cohort of 568 women. J Hypertension 1996; 14:729-36.

29. Welty FK, Ordovas J, Schaefer EJ, Wilson PWF, Young SG. Identification and molecular analysis of two ApoB gene mutations causing low plasma cholesterol levels. Circulation 1995; 92:2036-40.

30. Harris T, Feldman JJ, Kleinman JC, Ettinger WH, Makuc DM, Schatzkin AG. The low cholesterol mortality association in a national cohort. J Clin Epidemiol 1992; 45:595-601.

31. Kreger BE, Anderson KM, Schatzkin A, Splansky GL. Serum cholesterol level body mass index and the risk of colon cancer - The Framingham Study. Cancer 1992; 70:1038-43.

32. Morgan RE, Palinkas LA, Barrettconnor EL, Wingard DL. Plasma cholesterol and depressive symptoms in older men. Lancet 1993; 341:75-9.

33. Law MR, Thompson SG, Wald NJ. Assessing possible hazards of reducing serum cholesterol. Br Med J 1994; 308:373-9.

34. Penttinen J. Hypothesis: low serum cholesterol suicide and interleukin-2. Am J Epidemiol 1995; 141:716-8.

35. Wannamethee G, Shaper AG, Whincup PH, Walker M. Low serum total cholesterol concentrations and mortality in middle aged British men. Br Med J 1995; 311:409-13.

36. Golier JA, Marzuk PM, Leon AC, Weiner C, Tardiff K. Low serum cholesterol level and attempted suicide. Am J Psychiatry 1995; 152:419-23.

37. Kaplan JR, Shively CA, Fontenot MB, Morgan TM, Howell SM, Manuck SB, et al. Demonstration of an association among dietary cholesterol, central serotonergic activity and social behavior in monkeys. Psychosom Med 1994; 56:479-84.

38. Zhao B, Dierichs R, Harrachruprecht B, Winterhorff H. Oxidized LDL induces serotonin release from blood platelets. Am J Hematol 1995; 48:285-7.

39. Steegmans PHA, Fekkes D, Hoes AW, Bak AAA, Vanderdoes $\mathrm{E}$, Grobbee DE. Low serum cholesterol concentration and serotonin metabolism in men. Br Med J 1996; 312:221.

40. Gonzalez MJ, Schemmel RA, Dugan L, Gray J, Welsch CW. Dietary fish oil inhibits human breast carcinoma growth. A function of increased lipid peroxidation. Lipids 1993; $28: 827-32$.
41. Welsch CW. Review of the effects of dietary fat on experimental mammary gland tumorigenesis: role of lipid peroxidation. Free Radical Biol Med 1995; 18:757-73.

42. Yoshikawa T, Kokura S, Tainaka K, Naito Y, Kondo M. A novel cancer therapy based on oxygen radicals. Cancer Res 1995; 55:1617-20.

43. Raal FJ, Areias AJ, Pilcher GJ, Joffe BI, Seftel HC. Lack of effect of high dose vitamin $E$ on xanthoma regression in homozygous familial hypercholesterolaemia. Atherosclerosis 1994; 107:213-9.

44. Sasahara M, Raines EW, Chait A, Carew TE, Steinberg D, Wahl PW, Ross RJ. Inhibition of hypercholesterolemia-induced atherosclerosis in the non-human primate by probucol. 1. Is the extent of atherosclerosis related to resistance of LDL to oxidation? Clin Invest 1994; 94:155-64.

45. Fruebis J, Steinberg D, Dresel HA, Carew TE. A comparison of the antiatherogenic effects of probucol and of a structural analogue of probucol in low density lipoprotein receptor-deficient rabbits. J Clin Invest 1994; 94:392-8.

46. Kleinveld HA, Demacker PNM, Stalenhoef AFH. Comparative study on the effect of low-dose vitamin $E$ and probucol on the susceptibility of LDL to oxidation and the progression of atherosclerosis in Watanabe heritable hyperlipidemic rabbits. Arterioscler Thromb 1994; 14:1386-91.

47. Kleinveld HA, Haklemmers HLM, Hectors MPC, Defouw NJ, Demacker PNM, Stalenhoef AFH. Vitamin E and fatty acid intervention does not attenuate the progression of atherosclerosis in Watanabe heritable hyperlipidemic rabbits. Arterioscler Thromb Vasc Biol 1995; 15:290-7.

48. Raal FJ, Areias AJ, Waisberg R, Vonarb M. Susceptibility of low density lipoprotein to oxidation in familial hypercholesterolaemia. Atherosclerosis 1995; 15:9-15.

49. Fruebis J, Carew TE, Palinski W. Effect of vitamin E on atherogenesis in LDL receptor-deficient rabbits. Atherosclerosis 1995; 117:217-24.

50. Raal FJ, Areias AJ, Joffe BI. Low density lipoproteins and atherosclerosis - quantity or quality? Redox Rep 1995; 1:171-6.

51. Kleinveld HA, Demacker PNM, Dehaan AFF, Stalenhoef AFH. Decreased in vitro oxidizability of low-density lipoprotein in hypercholesterolemic patients treated with 3-hydroxy3-methylglutaryl-CoA reductase inhibitors. Eur J Clin Invest 1993; 23:289-95.

52. Aviram M. Interaction of oxidized low density lipoprotein with macrophages in atherosclerosis, and the antiatherogenicity of antioxidants Eur J Clin Chem Biochem 1996, 34:599-608.

Received September 18/December 4, 1996

Corresponding author: Bedrich J. Mosinger, MD, DSc, Institute for Clinical and Experimental Medicine, 12 Dolnojircanska, CZ-14200 Prague 4, Czech Republic 